7 Ács N, Bánhidy F, Puhó E, Czeizel AE. Pregnancy complications and delivery outcomes of pregnant women with influenza.J Matern Fetal Neonatal Med 2006; 19: 135-40.

8 Irving WL, James DK, Stephenson T, et al. Influenza virus infection in the second and third trimesters of pregnancy: a clinical and seroepidemiological study. BJOG 2000; 107: 1282-89.

9 France EK, Smith-Ray R, McClure D, et al. Impact of maternal influenza vaccination during pregnancy on the incidence of acute respiratory illness visits among infants. Arch Pediatr Adolesc Med 2006; 160: $1277-83$.

10 Black SB, Shinefield HR, France EK, Fireman BH, Platt ST, Shay D. Effectiveness of influenza vaccine during pregnancy in preventing hospitalizations and outpatient visits for respiratory illness in pregnant women and their infants. Am J Perinatol 2004; 21: 333-39.

11 Zaman K, Roy E, Arifeen SE, et al. Maternal influenza immunization in mothers and infants. N EnglJ Med 2008; published online Sept 17; DOI:10.1056/NEJMoa0708630.

12 Russell CA, Jones TC, Barr IG, et al. The global circulation of seasonal influenza A (H3N2) viruses. Science 2008; 320: 340-46.

13 Munoz FM, Greisinger AJ, Wehmanen OA, et al. Safety of influenza vaccination during pregnancy. Am J Obstet Gynecol 2005; 192: 1098-106.

14 Heinonen OP, Slone D, Shapiro S. Birth defects and drugs in pregnancy. Littleton, MA: Publishing Sciences Group Inc, 1977: 1-516.
15 Institute of Medicine. Immunization safety review: vaccines and autism. Washington, DC: The National Academy Press, 2004.

16 European Agency for the Evaluation of Medicinal Products. EMEA public statement on thiomersal in vaccines for human use-recent evidence supports safety of thiomersal-containing vaccines. London, 24 March. 2004. EMEA/CPMP/VEG/1194/04. http://www.emea.europa.eu/pdfs/ human/press/pus/119404en.pdf (accessed Sept 29, 2008).

17 Global Advisory Committee on Vaccine Safety. Statement on thiomersal. July, 2006. http://www.who.int/vaccine_safety/topics/thiomersal/ statement200308/en/index.html (accessed Sept 26, 2008).

18 US Food and Drug Administration. Thimerosal in vaccines. Updated June 3 , 2008. http://www.fda.gov/cber/vaccine/thimerosal.htm (accessed Sept 26 2008).

19 National Toxicology Program. Thimerosal [54-64-8]. Nomination to the National Toxicology Program. Review of the literature. April 2001. http:// ntp.niehs.nih.gov/ntp/htdocs/Chem_Background/ExSumPdf/Thimerosal. pdf (accessed Sept 26, 2008).

20 Varricchio $F$, Iskander J, Destefano $F$, et al. Understanding vaccine safety information from the Vaccine Adverse Event Reporting System. Pediatr Infect Dis J 2004; 23: 287-94.

\title{
Hepatosplenic cat-scratch fever with seropositivity for Bartonella quintana?
}

In the Clinical Picture by Federico Laham and Sheldon Kaplan, ${ }^{1}$ we found an unexplained inconsistency between the clinical description of the case, which clearly could be related to a cat-scratch disease (history of cat scratch to the face), and the serological results, which are more indicative of a causative role for Bartonella quintana, instead of Bartonella henselae (antibody titres 1/32768 and $1 / 2048$, respectively). $B$ henselae is transmitted by cat scratch and causes a regional lymphadenitis, whereas $B$ quintana, transmitted by body louse bites, was responsible for the "classic" trench fever (especially during World Wars I and II). At present, B quintana is related to chronic lymphadenopathy, bacteraemia, endocarditis, bacillary angiomatosis, and peliosis in patients with advanced HIV infection, and bacteraemia, with and without endocarditis, in homeless people without HIV infection, most notably in Seattle, WA, USA, and Marseille, France. ${ }^{2,3}$

In a case clinically similar to that described by Laham and Kaplan-ie, an immunocompetent man with a 3-day history of progressive right retromandibular swelling-but without fever and weight loss or other symptoms and signs, and without history of cat contact or cat scratch, we isolated a B quintana strain from the enlarged parotid gland of the patient (Mansueto $\mathrm{P}$ et al, unpublished data). Serology was negative for $B$ henselae and positive for $B$ quintana (IgG $1 / 256$ [normal less than 1/64] and $\operatorname{lgM} 1 / 40$ [normal less than $1 / 20$ ], respectively).

In the case report from Seattle, ${ }^{2}$ B quintana was isolated from the blood specimens of ten homeless patients with fever and persistent bacteraemia: three patients reported a recent cat scratch, five had scabies, and one had body lice. Perhaps Bartonella spp have many things still to tell.

Salvatore Incandela, Didier Raoult, Giustina Vitale, Anna Micalizzi, *Pasquale Mansueto

Department of Otorhinolaryngologic Sciences (SI), and Department of Clinical Medicine and Emerging Pathologies (GV, AM, PM), University of Palermo, Palermo, Italy; and Faculty of Medicine, Unité des Rickettsies, WHO Collaborative Center for Rickettsial Reference and Research, Marseille, France (DR) pamansu@unipa.it

We declare that we have no conflicts of interest.

1 Laham FR, Kaplan SL. Hepatosplenic cat-scratch fever. Lancet Infect Dis 2008; 8: 140.

2 Spach DH, Kanter AS, Dougherty MJ, et al. Bartonella (Rochalimaea) quintana bacteremia in inner-city patients with chronic alcoholism. N EnglJ Med 1995; 332: 424-28.

3 Brouqui P, Lascola B, Roux V, Raoult D. Chronic Bartonella quintana bacteremia in homeless patients. N Engl J Med 1999; 340: 184-89.

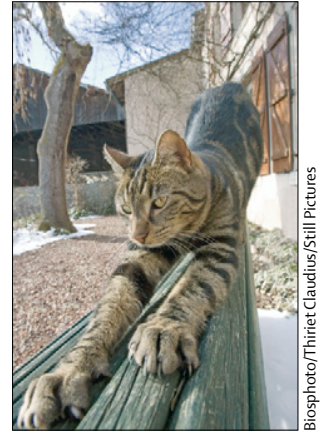

